\title{
Removal of Chromium from Water Environment by Forward Osmosis System
}

\author{
Minh Tuan PHAM, Syouhei Nishinama, and Kazuharu YoshizUKA* \\ Department of Chemical Engineering, The University of Kitakyushu, Hibikino 1-1, Kitakyushu, 808-0135, Japan
}

\begin{abstract}
Forward osmosis (FO) technology has been applied for removal of chromium ( $\mathrm{Cr}$ ) from water environment. Comparison of the removal efficiency of $\mathrm{Cr}(\mathrm{VI})$ and $\mathrm{Cr}(\mathrm{III})$ was investigated by changing several operational conditions. The $\mathrm{pH}$ of feed solution plays an important role in rejection of $\mathrm{Cr}$. The $\mathrm{Cr}(\mathrm{VI})$ rejection was increased with increasing $\mathrm{pH}$, while $\mathrm{Cr}(\mathrm{III})$ rejection was stable. It also demonstrated that the rejection of $\mathrm{Cr}$ was higher when the membrane active layer faces the feed solution compared to the rejection when the membrane active layer faces the draw solution.
\end{abstract}

\section{Introduction}

Heavy metals are naturally occurring elements that have high atomic weight and a density at least 5 times greater than that of water. Their multiple industrial, domestic, agricultural, medical, and technological applications have led to their wide distribution in the environment; raising concerns over their potential effects on human health and the environment (Tchounwou et al., 2012). Chromium $(\mathrm{Cr})$ is a toxic industrial pollutant that is classified as human carcinogen by several regulatory and nonregulatory agencies. The health hazard associated with exposure to $\mathrm{Cr}$ depends on its oxidation state, ranging from the low toxicity of the metal form to the high toxicity of the hexavalent form (Velma et al., 2009; Atsdr, 2012). Therefore, development of more effective treatments for mixtures of harmful compounds is required.

In previous studies, the removal of heavy metals with several traditional treatments was examined, and advanced technologies were developed (Barakat, 2011). Membrane technology has been proven as a feasible option in wastewater treatment, due to its high rejection to contaminants, such as organic compounds or dye molecules, and low fabrication cost. Nanofiltration (NF) and reverse osmosis (RO) were proved their effectiveness in removing heavy metals from polluted water. However, both processes are operated at high pressures and have relatively low water-recovery rates. Therefore, comparatively high costs are incurred, and there is a high risk of severe membrane fouling (Alzahrani et al., 2013). Forward osmosis (FO) is an emerging water treatment technology, and has gained increasing interest in recent years. FO is a membrane process in which water flows across a semi-permeable membrane from a feed solution of lower osmotic pressure to a draw solution of higher osmotic pressure (Cath et al., 2006). FO is highly attractive due to its lower fouling potential, simplicity, and higher recovery (Cath et al., 2005), although energy consumption could be high if draw solution regeneration is required. Potential applications of FO include seawater desalination (McCutcheon et al., 2006), wastewater reclamation, liquid food processing (Petrotos et al., 1999), and electricity generation via a derivative pressure retarded osmosis process. When evaluating FO as a treatment process for water treatment, it is important to ensure that trace contaminants such as $\mathrm{Cr}$ are removed from the treated water. Thus, a fundamental understanding of $\mathrm{Cr}$ transport in $\mathrm{FO}$ membrane processes is critical to the effective development of FO membrane technology. Despite the importance of this aspect, very few studies on the removal of trace contaminants by FO have been reported in the literature. However, the performance of FO membranes in removing the various $\mathrm{Cr}$ species from aqueous solution in the presence of different environmental conditions, has not yet been reported. The various factors and related mechanisms that control the removal of $\mathrm{Cr}$ by $\mathrm{FO}$ membranes need to be elucidated for a better understanding of the separation mechanisms.

The aim of this study is to find out the effectiveness of FO to be used for the removal of $\mathrm{Cr}$. In this work, the separation behavior was studied by a set of experiments at various conditions including $\mathrm{pH}$, membrane orientation, feed and draw solution concentration.

\section{Experimental}

All chemical reagents were purchased from Wako Pure Chemical Industries, Ltd. (Osaka, Japan).

The FO experiments were carried out using commercial flat thin-film composite (TFC) FO membrane (Sterlitech Corporation, WA, USA). The FO membrane cell was made of natural acetal copolymer (CF042 FO, Sterlitech Corporation, WA, USA), a thin polyamide layer (around $200 \mathrm{~nm}$ ) deposited on top of a polysulfone porous layer (about $50 \mu \mathrm{m}$ ) on top of a non-

\footnotetext{
* Corresponding author: yoshizuka@kitakyu-u.ac.jp
} 


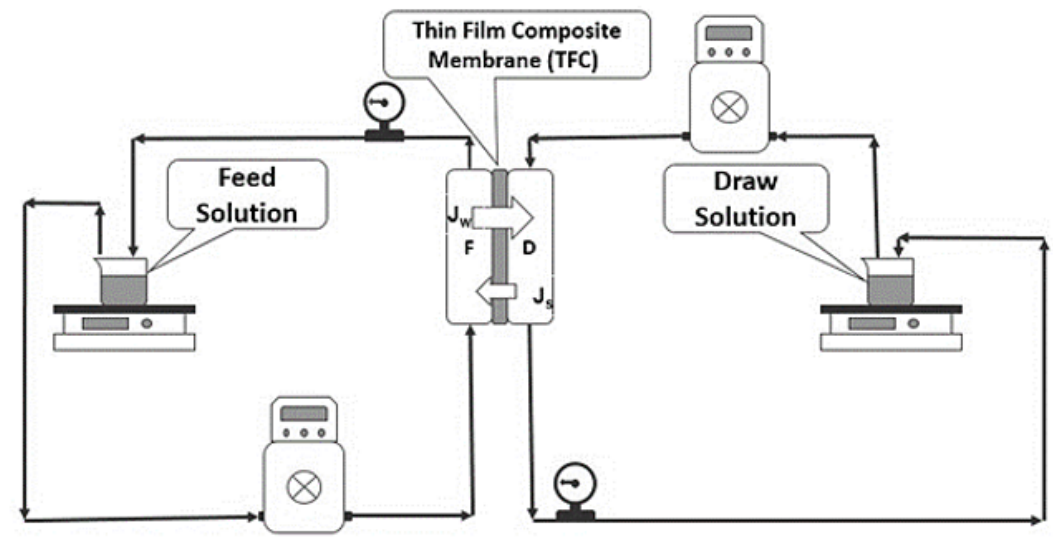

Figure 1. Forward osmosis experimental set-up

woven fabric support sheet. The FO membrane module comprised a cross-flow membrane cell with two channels for the feed and draw solution. The channel has dimensions of $9.2 \mathrm{~cm}$ length, $4.6 \mathrm{~cm}$ width, and $0.2 \mathrm{~cm}$ height, providing an effective membrane area of $42 \mathrm{~cm}^{2}$. A peristaltic pump was used to recirculate the feed and draw. A constant cross-flow rate of $0.25 \mathrm{~L} / \mathrm{min}$ was maintained between the two closed loops for the feed and draw solution in the system. Reservoirs were digitally weighed, and their weight changes were recorded at regular time intervals. $\mathrm{pH}$ and conductivity meters were used to monitor the quality variation of the solutions in 60 min intervals.

Feed solution having concentration of $\mathrm{Cr}(\mathrm{VI})$ and $\mathrm{Cr}(\mathrm{III})$ were prepared by dissolving the required amount $\mathrm{Na}_{2} \mathrm{CrO}_{4} \cdot 4 \mathrm{H}_{2} \mathrm{O}$ and $\mathrm{Cr}\left(\mathrm{NO}_{3}\right)_{3} \cdot 9 \mathrm{H}_{2} \mathrm{O}$ in deionized water. Temperature of the feed and draw solutions were maintained at room temperature $\left(25 \pm 1^{\circ} \mathrm{C}\right)$. The experiment was conducted after stabilizing the system ( $\sim 30 \mathrm{~min}$ ), and the samples were collected from both the feed and draw solution, respectively, in $60 \mathrm{~min}$ time intervals to quantify the total concentration of tested metals. The solution conductivity and $\mathrm{pH}$ were measured in 60 minutes time interval, respectively. Due to the pure water was transported from feed to draw by the FO process, the volume of the feed reservoir decreased and the volume of draw solution increased over time were recorded continually. Solution $\mathrm{pH}$ was adjusted to $4-8$ by adding $0.1 \mathrm{M}[=\mathrm{mol} / \mathrm{L}] \mathrm{HCl}$ or $0.1 \mathrm{M} \mathrm{NaOH}$. The total feed solution volume was $0.5 \mathrm{~L}$. Deionized water was used for preparing sodium chloride $(\mathrm{NaCl})$ as draw solution with concentration of $0.5,1,1.5$ and $2 \mathrm{M}$. The total draw solution volume was $0.5 \mathrm{~L}$. This sodium chloride $\mathrm{NaCl}$ was selected in preparation of draw solutions because it has low molecular weight, low viscosity, high solubility, high osmotic pressure that can be given by this solution, nontoxic, easily and economically separated and recycled.

The schematic of lab-scale FO system and the module picture were shown in the Figure 1. The membrane was used in active layer facing feed solution (AL-FS) mode, with draw solution facing the membrane support layer and the feed solution facing the active layer. The performance of the FO process was investigated by varying the operating factors $\mathrm{pH}$, solutes initial concentration, draw solution concentration, and membrane orientation. During the experiment, the conductivity and $\mathrm{pH}$ of the solutions were measured at 1 hour time intervals, and $1 \mathrm{ml}$ sample was collected from draw solution in each hour for analysis. The volumes variation of 2 tanks within the experiment period were measured and the mass balance was calculated after each experiment.

The FO water flux $\left(J_{w}\right)$ was obtained by measuring the weight change of the draw solution according to the Eq. (1):

$$
J_{w}=\Delta V /\left(A_{m} \Delta t\right)=(\Delta m / \rho) /\left(A_{m} \Delta t\right)
$$

where $\Delta V$ and $\Delta m$ is the volume change and weight change of the draw solution over the operation time interval $\Delta t, \rho$ is the density of feed solution, and $A_{m}$ is the effective membrane area. The solute rejection $R[\%]$ was defined as the percentage of feed solutes that were retained by the membrane. It was calculated as:

$$
R=\left[1-\left(C_{d} V_{d} / V_{p} C_{f}\right)\right] \times 100
$$

where $C_{d}[\mathrm{mg} / \mathrm{L}]$ is the $\mathrm{Cr}$ concentration in the draw solution at the end of each FO test, $V_{d}[\mathrm{~L}]$ is the final volume of draw solution, $V_{p}[\mathrm{~L}]$ is the volume of the permeate water, and $C_{f}[\mathrm{mg} / \mathrm{L}]$ is the $\mathrm{Cr}$ concentration in the feed solution. $C_{d}[\mathrm{mg} / \mathrm{L}]$ was determined by inductively coupled plasma atomic emission spectrometry (ICP-AES). Conductivity and $\mathrm{pH}$ of the solutions were also measured by using a conductivity (Horiba DS-51) and $\mathrm{pH}$ meter (Horiba model F-74). The average and standard deviation of $\mathrm{Cr}$ removal and water flux was obtained experimentally following the time from the collected data. The error bars for each experiment represent the standard deviation of 3 measurements.

\section{Results and Disscussion}

\subsection{Effect of $\mathrm{Cr}$ initial concentration on As rejection and water flux}

The effect of $\mathrm{Cr}$ feed solution concentration on removal efficiency and water flux in AL-FS mode membrane orientation is shown in Figure 2. Average water flux for $\mathrm{Cr}(\mathrm{VI})$ and $\mathrm{Cr}(\mathrm{III})$ were $5.3 \mathrm{Lm}^{-2} \mathrm{~h}^{-1}$ and 6 $\mathrm{Lm}^{-2} \mathrm{~h}^{-1}$, respectively, which were constant over the entire range of feed solution concentration investigated (10 
$\mathrm{mg} / \mathrm{L}$ to $100 \mathrm{mg} / \mathrm{L})$. The $\mathrm{Cr}(\mathrm{VI})$ rejection was increased with increasing feed solution concentration, while the $\mathrm{Cr}$ (III) rejection was stable. The $\mathrm{Cr}(\mathrm{VI})$ rejection was increased, because the ratio between the feed solution concentration and solute flux is not proportional. Increase in the $\mathrm{Cr}(\mathrm{VI})$ concentration in the feed solution simultaneously increases the $\mathrm{Cr}(\mathrm{VI})$ solute flux passing through membrane. When the inital concentration of $\mathrm{Cr}(\mathrm{VI})$ increases in tenfold from $10 \mathrm{mg} / \mathrm{L}$ to $100 \mathrm{mg} / \mathrm{L}$, the $\mathrm{Cr}$ solute flux $\left(J_{S}\right)$ however increases just 7 times. Therefore, the ratio $\left(J_{s} / J_{w} C_{f}\right)(\mathrm{Eq}(2))$ was decreased while rejection was increased. The rejection of $\mathrm{Cr}$ (III) occurs due to larger hydrated radii $(0.9 \mathrm{~nm})$ (Al-Haj-Ali and Marashdeh, 2014) and larger than 2 times of membrane pore (Xie et al., 2014). As a result, a significant effect of initial $\mathrm{Cr}$ (III) concentration on rejection was observed.

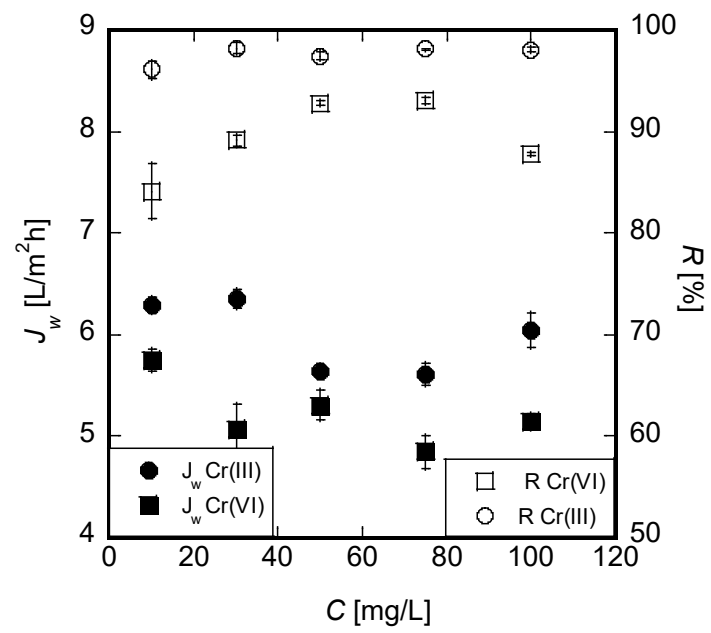

Figure 2. Effect of feed concentration on water flux and $\mathrm{Cr}$ removal

\subsection{Effect of draw solution concentration on $\mathrm{Cr}$ rejection and water flux}

Figure 3 shows the effect of draw solution concentration on the water flux and $\mathrm{Cr}$ rejection in FO system. Due to the increase of the osmotic pressure for both case of $\mathrm{Cr}$, the water flux increase with increase of draw solution concentration. The water flux in the case of $\mathrm{Cr}$ (III) was higher than that of $\mathrm{Cr}(\mathrm{VI})$. The rejection of $\mathrm{Cr}(\mathrm{VI})$ increased with increasing draw solution concentration, due to the related increase of the applied osmotic pressure, which yields a dilution effect, however, this was not as significant as the water flux. The rate of increase in water flux $J_{w}$ was much higher than the rate of $\mathrm{Cr}$ solute flux $J_{s}$ across the membrane, with the increase of the draw solution concentration. Therefore, the rejection increase (from $83.7 \%$ to $87.3 \%$ ) as the effective concentration of solutes $\left(J_{s} / J_{w}\right)$ permeated through the membrane was low due to comparatively high water flux (Eq. (2)). The rejection of solute is dependent on the characteristics and properties of the membranes used for separation, so the $\mathrm{Cr}$ (III) rejection was stable for the range of draw solution concentration (from $0.5 \mathrm{M}$ to $2 \mathrm{M}$ ) because of its larger hydrated radii.

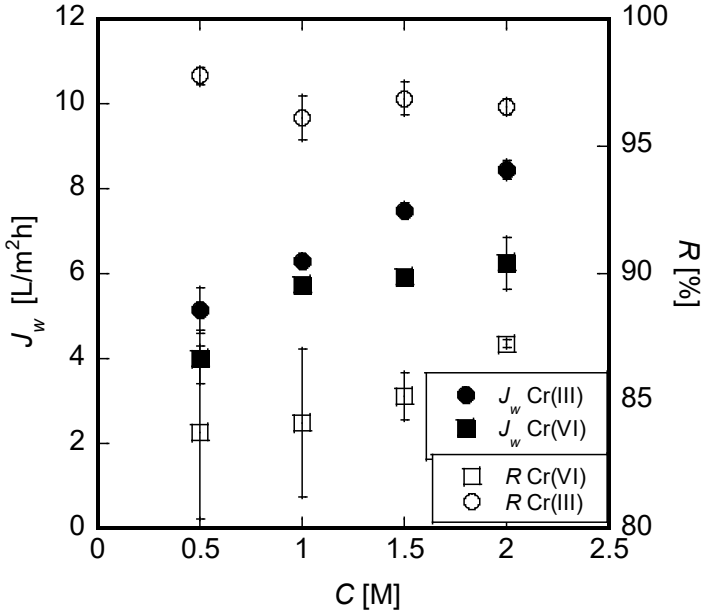

Figure 3. Effect of draw solution concentration on water flux and $\mathrm{Cr}$ removal

\subsection{Effect of $\mathrm{pH}$ on $\mathrm{Cr}$ rejection and water flux}

The effect of the $\mathrm{pH}$ of the feed solution on $\mathrm{Cr}$ removal and water flux in AL-FS mode membrane orientation is shown in Figure 4. The experiment was carried out in $\mathrm{pH}$ varied from 4 to 8 . The water flux for $\mathrm{Cr}(\mathrm{VI})$ was stable at $5.2 \mathrm{Lm}^{-2} \mathrm{~h}^{-1}$ while water flux for $\mathrm{Cr}$ (III) was slightly bell shape against $\mathrm{pH}$. This can be explained by the range of difference in dissociated form of trivalent chromium in water environment (Girard, 2013):

$$
\begin{array}{ll}
\mathrm{Cr}^{3+}+\mathrm{H}_{2} \mathrm{O} \Leftrightarrow \mathrm{Cr}(\mathrm{OH})^{2+}+\mathrm{H}^{+} & \left(K_{1}=10^{-4}\right) \\
\mathrm{Cr}(\mathrm{OH})^{2+}+\mathrm{H}_{2} \mathrm{O} \Leftrightarrow \mathrm{Cr}(\mathrm{OH})_{2}^{+}+\mathrm{H}^{+} & \left(K_{2}=10^{-5.62}\right) \\
\mathrm{Cr}(\mathrm{OH})_{2}{ }^{+}+\mathrm{H}_{2} \mathrm{O} \Leftrightarrow \mathrm{Cr}(\mathrm{OH})_{3}+\mathrm{H}^{+} & \left(K_{3}=10^{-7.13}\right) \\
\mathrm{Cr}(\mathrm{OH})_{3}+\mathrm{H}_{2} \mathrm{O} \Leftrightarrow \mathrm{Cr}(\mathrm{OH})_{4}^{-}+\mathrm{H}^{+} & \left(K_{4}=10^{-11.02}\right)
\end{array}
$$

It can be seen that at $\mathrm{pH} 8$, the dominant form of $\mathrm{Cr}$ (III) was $\mathrm{Cr}(\mathrm{OH})_{3}$, precipitation form, therefore it might block membrane pore and hinder the water permeating through membrane. As the result, reducing water flux was observed. The effect of $\mathrm{pH}$ on the rejection of $\mathrm{Cr}$ (III) was insignificant, the rejection was stable around $97.5 \%$. The $\mathrm{Cr}(\mathrm{VI})$ rejection increased with an increase in the $\mathrm{pH}$. The $\mathrm{Cr}(\mathrm{VI})$ rejection increase from $60.9 \%$ to $89.9 \%$. This can be explained by considering the following dissociation equilibrium (Kučić et al., 2018):

$$
\begin{array}{ll}
\mathrm{H}_{2} \mathrm{CrO}_{4} \Leftrightarrow \mathrm{HCrO}_{4}^{-}+\mathrm{H}^{+} & \left(K_{1}=1.21\right) \\
\mathrm{Cr}_{2} \mathrm{O}_{7}^{2-}+\mathrm{H}_{2} \mathrm{O} \Leftrightarrow \mathrm{HCrO}_{4}^{--} & \left(K_{2}=35.5\right) \\
\mathrm{HCrO}_{4}^{-} \Leftrightarrow \mathrm{CrO}_{4}^{2-}+\mathrm{H}^{+} & \left(K_{3}=3.10^{-7}\right)
\end{array}
$$

From the above equation it is clear that with an increase in $\mathrm{pH}$ of the solution, the dominant $\mathrm{Cr}(\mathrm{VI})$ species becomes more negatively charged. As a result, electrostatic repulsion increases between the negatively charged FO membranes (Kim et al., 2012) and the negative oxy-anionic $\mathrm{Cr}$ species. Therefore, a higher rejection of $\mathrm{Cr}(\mathrm{VI})$ with increasing $\mathrm{pH}$ was achieved. 


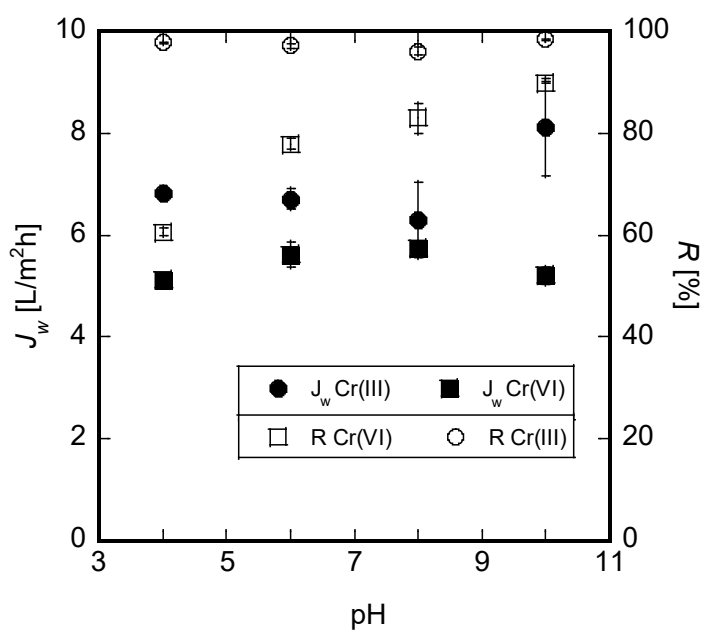

Figure 4. Effect of $\mathrm{pH}$ on water flux and $\mathrm{Cr}$ removal

\subsection{Effect of membrane orientation on $\mathrm{Cr}$ removal and water flux}

The effect of membrane orientation, either AL-FS (active layer facing feed solution) of AL-DS (active layer facing draw solution) on $\mathrm{Cr}$ removal and water flux is shown in Figure 5. The rejection of $\mathrm{Cr}$ in AL-FS mode was higher than in AL-DS mode while water flux in AL-DS mode was higher than in AL-FS mode. Internal concentration polarization and external concentration polarization play an important role in the $\mathrm{Cr}$ separation as well as in water flux with respect to the membrane orientation.

In AL-FS mode, to obtain a considerable amount of water flux, osmotic pressure of draw solution at the draw solution side needs to be higher than osmotic pressure at the membrane surface. However, the solute concentration at the feed solution side and active layer-support layer interface is insignificant in AL-FS mode, therefore, dilutive internal concentration polarization become predominant (as water passes across the membrane from feed solution to draw solution side) resulting in decrease of water flux due to lowering of the net osmotic pressure across the active layer by diluting the draw solution (McCutcheon and Elimelech, 2006).

The higher rejection of $\mathrm{Cr}$ in AL-FS mode compared to AL-DS mode was attributed due to low external concentration polarization of $\mathrm{Cr}$ at membrane active layer. In AL-FS mode, after diffusion of $\mathrm{Cr}$ through active layer is immediately carried away by the water flux, leaving no chance of accumulation on active layer-support layer interface. Thus, the $\mathrm{Cr}$ concentration at the active layersupport layer interface was nearly the same and $\mathrm{Cr}$ experienced less internal concentration polarization, resulting in a high rejection. However, in AL-DS mode, the feed $\mathrm{Cr}$ can easily permeate through the porous support layer by diffusion and accumulate at the supportactive layer interface due to the retention of $\mathrm{Cr}$ by the active layer. Consequently, there is a simultaneous increase in the $\mathrm{Cr}$ concentration gradient across the membrane active layer (concentrative internal concentration polarization of $\mathrm{Cr}$ ), resulting in more permeation of $\mathrm{Cr}$.

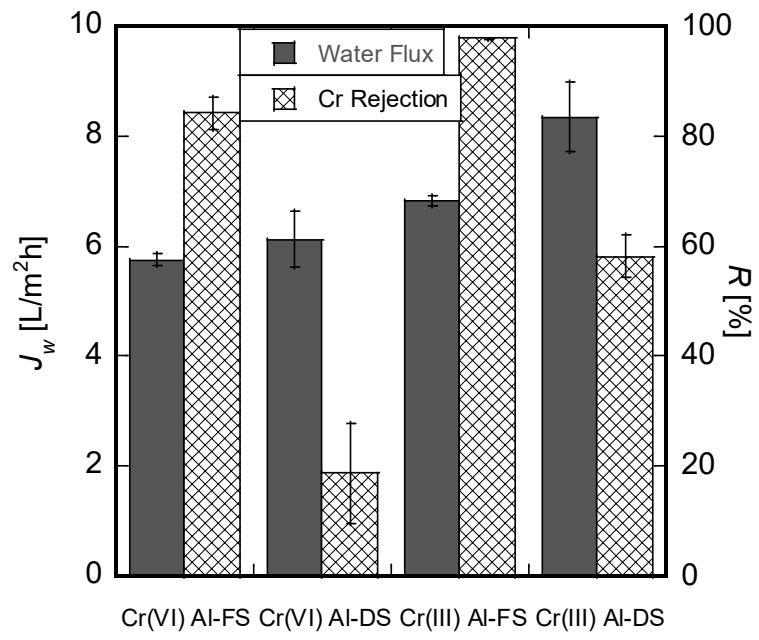

Figure 5. Effect of membrane orientation on water flux and $\mathrm{Cr}$ removal

\section{Conclusion}

A forward osmosis (FO) process for the removal of chromium from water environment was demonstrated in order to establish a more effective water treatment process. The $\mathrm{Cr}$ removal from water environment by $\mathrm{FO}$ membrane was investigated by using $\mathrm{NaCl}$ as the draw solution. The effect of $\mathrm{pH}$ of the feed solution, the draw solution concentration and the membrane orientation were examined to evaluate the efficiency of FO as a barrier for removal of heavy metal from aqueous solution. The water flux dramatically increase with the increase of draw solution concentration. It was also indicated that the rejection of $\mathrm{Cr}$ was higher when the membrane active layer faces the feed solution compared to the rejection when the membrane active layer faces draw solution. However, for $\mathrm{Cr}(\mathrm{III})$, it was observed that the rejection was stable at all range of $\mathrm{pH}$, while it can be seen that the $\mathrm{Cr}(\mathrm{VI})$ rejection was increased with increasing in the $\mathrm{pH}$. Because the electrostatic repulsion increases between the negatively charged FO membranes. In the case of $\mathrm{Cr}$ (III), much higher rejection was obtained, because its hydrated radii is larger than that of $\mathrm{Cr}(\mathrm{VI})$.

\section{References}

Al-Haj-Ali, A. and L. Marashdeh; "Removal of Aqueous Chromium(III) Ions Using Jordaniannatural Zeolite Tuff in Batch and Fixed Bed Modes," Jordan J. Earth Environ. Sci., 6(2), 45-51 (2014)

Alzahrani, S., A. W. Mohammad, N. Hilal, P. Abdullah and O. Jaafar; "Comparative Study of Nf and Ro Membranes in the Treatment of Produced Water-Part I: Assessing Water Quality," Desalination, 315, 18-26 (2013)

Atsdr, S.; "Toxicological Profile for Chromium. Agency for Toxic Substances and Disease Registry," Public 
Health Service, US Department of Health and Human Services, http://www. atsdr. cdc. gov/toxprofiles/tp.asp (2012)

Barakat, M.; "New Trends in Removing Heavy Metals from Industrial Wastewater," Arabian J. Chem., 4(4), 361-377 (2011)

Cath, T. Y., D. Adams and A. E. Childress; "Membrane Contactor Processes for Wastewater Reclamation in Space: Ii. Combined Direct Osmosis, Osmotic Distillation, and Membrane Distillation for Treatment of Metabolic Wastewater," J. Membr. Sci., 257(1-2), 111-119 (2005)

Cath, T. Y., A. E. Childress and M. Elimelech; "Forward Osmosis: Principles, Applications, and Recent Developments," J. Membr. Sci., 281(1-2), 70-87 (2006)

Girard, J. E.; Principles of Environmental Chemistry, Jones \& Bartlett Publishers, Burlington, U.S.A. (2013).

Kim, C., S. Lee, H. K. Shon, M. Elimelech and S. Hong; "Boron Transport in Forward Osmosis: Measurements, Mechanisms, and Comparison with Reverse Osmosis," $J$. Membr. Sci., 419, 42-48 (2012)

Kučić, D., M. Simonič and L. Furač; "Batch Adsorption of Cr (Vi) Ions on Zeolite and Agroindustrial Waste," Chem. Biochem. Eng. Quarterly, 31(4), 497-507 (2018)

McCutcheon, J. R. and M. Elimelech; "Influence of Concentrative and Dilutive Internal Concentration Polarization on Flux Behavior in Forward Osmosis," $J$. Membr. Sci., 284(1-2), 237-247 (2006)

McCutcheon, J. R., R. L. McGinnis and M. Elimelech; "Desalination by Ammonia-Carbon Dioxide Forward Osmosis: Influence of Draw and Feed Solution Concentrations on Process Performance," J. Membr. Sci., 278(1-2), 114-123 (2006)

Petrotos, K. B., P. C. Quantick and H. Petropakis; "Direct Osmotic Concentration of Tomato Juice in Tubular Membrane-Module Configuration. Ii. The Effect of Using Clarified Tomato Juice on the Process Performance," J. Membr. Sci., 160(2), 171-177 (1999)

Tchounwou, P. B., C. G. Yedjou, A. K. Patlolla and D. J. Sutton; Heavy Metal Toxicity and the Environment, Molecular, Clinical and Environmental Toxicology, pp. 133-164, Springer, Basel, Switzerland (2012)

Velma, V., S. Vutukuru and P. B. Tchounwou; "Ecotoxicology of Hexavalent Chromium in Freshwater Fish: A Critical Review," Rev. Environ. Health, 24(2), 129-146 (2009)

Xie, M., L. D. Nghiem, W. E. Price and M. Elimelech; "Relating Rejection of Trace Organic Contaminants to Membrane Properties in Forward Osmosis: Measurements, Modelling and Implications," Water Res., 49, 265-274 (2014) 